\title{
Incumbent Communication Strategies VS Empty Boxes in Semarang Local Election 2020
}

\author{
Nugraheni Arumsari ${ }^{1, *}$, Martien Herna Susanti ${ }^{2}$, Setiajid $^{3}$, Hafiz Rafi Uddin ${ }^{4}$ \\ 1,2,3,4 Department of Politics and Citizenship, Faculty of Social Sciences, Universitas Negeri Semarang \\ *Corresponding author. Email: nugraheni.arum@mail.unnes.ac.id
}

\begin{abstract}
In the current era of globalization, the existence of new media is very important because the multimedia aspect can be said to be the right means to communicate. Moreover, the presence of new media in the implementation of the Mayor Election of Semarang City (Pilwakot) on December 9, 2020 then became one of the alternative means of communication that was considered effective and efficient in the election campaign, particularly since the implementation of Mayor Election occurred in the midst of the Covid-19 pandemic. The implementation of the 2020 Regional Head Election in Semarang City is regulated in the Regulations of General Election Commission or PKPU Article 58 PKPU Number 13 of 2020. In this regard, this study was conducted to identify the political communication strategy used by the incumbent in winning the 2020 Semarang City Election. This study used descriptive qualitative research methods with data collection through semi-structured interviews, literature studies and studies of the content of social media messages. The research findings show that several strategies were used by Hendi-Ita to fight agains empty boxes. First is through the Success Team strategy. Second is the strategy of Hendi-Ita Supporting Community in each region. Third is the strategy for using new media in the midst of Covid-19 pandemic, such as Facebook, Instagram, Twitter, and online news media. Fourth is the Digital Campaign by utilizing existing social media through the accounts@smg-hit, @hendi_ita, and @ rehita_hebat @hendrarprihadi @mbakitasmg and also through the campaign box.
\end{abstract}

Keywords: strategy, communication, local election, new media.

\section{INTRODUCTION}

Digitization as an effect of globalization is part of technological progress which provides an opportunity for the birth of the internet that can be interpreted as international connection networking. One effect is the media that we know as New Media based on the internet (Twitter, Instagram, Facebook, Whatsapp, Youtube, etc.). According to data from the Indonesian Internet Service Providers Association (APJII) in 2020, there were $73.7 \%$ of active internet users throughout Indonesia. For the Central Java region itself, there were $78.8 \%$ of active internet users, while in Semarang there was $70 \%$. Among its users, the majority are young people. Therefore, it is correct to say that today's society depends on the internet including social media that can be accessed via smartphones.

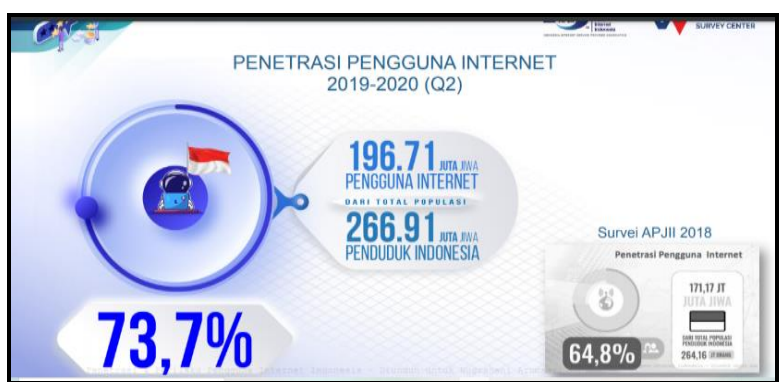

Figure 1. Internet User Data in Indonesia in 2020

In the current era of globalization, the existence of New Media is very important because the multimedia aspect is the right means for communicating. Moreover, the existence of New Media is considered effective and efficient in carrying out political communication strategies in the Semarang Local Election, which was held on December 9, 2020, especially in the midst of the Covid-19 pandemic. Therefore, the implementation of the 2020 Local Election in Semarang City was regulated 
in the Regulations of General Election Commission or PKPU Article 58 PKPU Number 13 of 2020 [1].

The use of New Media in politics is expected to optimize the quality of political participation. The presence of various features on the internet allows participants to be further involved in the selection or decision-making process. Therefore, some experts believe that the use of new media in the politics can fully realize the concept of public space as aspired by Jurgen Habermas [2]. Accodring to Habermas [3] public space is expected to have an important role in the democratic process. Public space is meant as a means of public discourse in conveying opinions, interests and needs.

Semarang city was chosen because it is a barometer of democracy in Central Java. In addition, voters in Semarang city are classified as rational voters. Rational voter behavior comes from people who are intelligent, critical, dare to demand, careful, and also not easily fooled by politics. Rational voters will consider the advantages for themselves before making their vote [4].

This became interesting when the incumbent in Semarang Mayor Election held in the midst of the Covid-19 pandemic on December 9, 2020 became the winner against an empty box. The problem can be formulated, namely how the incumbent COMMUNICATION STRATEGIES vs. empty box in Semarang Local Election 2020. This study aims to identify the communication strategies used by the incumbent in winning the 2020 Semarang Mayor Election.

\section{RESEARCH METHOD}

Research using the constructivist paradigm refers to [5] descriptive qualitative research method to describe or construct in-depth interviews with research subjects so as to provide a clear picture of the communication strategies used by the success team from the incumbent in winning the 2020 Semarang Local Election. This study was done by collecting data through semistructured interviews, literature studies and studying the message content in social media.

The subject and object of this study were the Success Team of the elected Mayor of Semarang in 2020 and also the people of Semarang city who participated directly in the 2020 simultaneous local elections. In addition, for the validity of the data, researchers used source triangulation referring to [6]. This study used data analysis techniques from Miles and Huberman [7], which is doing data reduction or the process of selecting and simplifying the raw data obtained [8]. Then, it continues with presentating the data and drawing conclusions in which contains a summary of each question.

\section{RESULT AND DISCUSSION}

Some communication carried out by the community certainly involved political content, especially during the Semarang Local Election where the public was able to actively give their opinions through the media, whether it is mass media or social media.

In the past, political communication activities could be carried out through meetings or gatherings which included distributing leaflets, pamphlets and also criticism of the government at that time. This resulted in the absence of democratic freedom which was limited freedom of expression in public, making people's political communication impossible to do in the public sphere [9]. But what is happening now is that people can be freeer in expressing their opinions. This is because of technological developments that allow people to initiate public spaces through private spaces called social media or new media. With the new media, political communication can be carried out freely even without intimidation from law enforcement. There are no more restrictions on expressing opinion.

As the elected pair in Mayor of Semarang for the 2021-2025 period, Hendrar Prihadi and Hevearita Gunaryanti Rahayu can be said to be a victory from social media. This is because social media inevitably participates in determining the vote of a candidate. Various forms of campaigns were carried out, whether through the success team, sponsors or sympathizer. Those campaign strategies were used amidst the uncertainty of the Covid-19 pandemic.

The Hendi-Ita pair received considerable support from various political parties. It can be said that almost all political parties support the incumbent in the 2020 Pilkada. Another interesting thing is that the majority of the political parties carrying this pair are the dominant political parties in the Semarang City DPRD. This was also expressed by Arnaz Agung Andrarasmara as the head of the volunteer coordinator for the Hendi-Ita.

"The support and synergy between the DPRD and Hendrar Prihadi has made it easier for coordination to build Semarang city. These parties are PDI-P, Golkar Party, PKB, Democratic Party, PKS, Gerindra Party, PAN, Nasdem Party, and PSI. Meanwhile, there are other supporting parties outside the supporting parties, namely PKPI, Hanura Party, Berkarya Party, PBB and PPP".

This is also shown by Hendi-Ita pair who have been known for their consistency in building Semarang city. The creation of a positive figure in the 2015 election campaign as a clean, friendly, and flexible personal figure has been firmly attached to the people's mind in Semarang City. Moreover, the Hendi-Ita pair are considered to have experience in managing Semarang. This is evidenced by the high level of enthusiasm from 
Semarang people in the 2020 Pilkada because it is purely from public awareness that is based on before and after difference, namely the condition of Semarang City before and after Hendi-Ita took office. The party platform is also quite influential where the main proponents of the Hendi-Ita pair are the PDI-P and Central Java. Those are the basis for supporting the PDI-P.

\section{Incumbent Hendi-Ita Communication Strategy}

\section{Success Team (Great Volunteer Team)}

The visions and missions offered in the 2020 Pilkada are continuing the development of the Semarang Smart City or continuing the visions and missions in the 2015 Pilkada. The success team does not emphasize the vision and mission too much, but the team emphasizes the performance results of the Hendi-Ita couple. Performance results are considered more real than just slogans and words.

The success team considers that the facts on the ground are more important than campaign promises that have not been realized. The public can see and feel the changes in Semarang city directly from time before to after being led by Hendi. This is the main force in the 2020 election campaign. Especially during the pandemic, life becomes more difficult than normal. Therefore, real leaders are needed in overcoming the problems faced by Semarang city.

The success teams outside the party are professionals where the members are the teams that fought in the 2015 local elections. In the 2020 elections, it can be said that the members of Hendrar Prihadi's success team are old people including influencers. This is what makes the success team optimistic that the movement through social media will be very effective. There is no addition or reduction in the number of members. The number of members of the winning center team in Pandanaran or also known as the Hendi Victory Post is 30 people. From this explanation, it is clear that there is consistency and solidity between members of the successful team, making it easier to develop new winning strategies during the COVID-19 pandemic. Campaign organizational structure still minimizes internal conflicts. It has been confirmed and proven that the efforts made are able to maintain the incumbent position as the Mayor of Semarang City.

\section{Hendi-Ita Support Community}

Communities supporting the incumbent in every area of Semarang City also participate in socializing and conducting campaigns to a large audience. These supporting communities are under the success team of Hendi-Ita. In addition, there were campaign posts in each of the supporting communities. The information provided by the central success team to the supporting community woul then be intensively disseminated to the public in each area of Semarang City. This strategy facilitates the dissemination of information to the smallest scope of the community that is villages. The number of these supporting communities is one of the things that support the winning of the Hendi-Ita pair.

\section{The Use of New Media}

Changes in the pattern of people's lives during the pandemic also have an impact on the way of communication and coordination between success teams and supporting communities. In the 2015 regional elections when conditions were still normal, discussions of political communication strategies and regular meetings were discussed in face-to-face forums. When entering the new normal era in the midst of the Covid19 pandemic, interaction activities directly or offline are now limited and switched to online meetings. Although they use mass media more often in meetings or discussions about election campaigns, face-to-face meetings are not completely eliminated. The number of meetings, however, is reduced and the health protocols are still implemented in accordance with government recommendations such as the limited number of members attending meetings, wearing masks, maintaining distance, using hand sanitizer, and washing hands.

The new restrictions and regulations applied during the new normal certainly change the focus of attention in the campaign itself. In the 2015 regional elections the Hendi-Ita pair fought other candidates, while in the 2020 regional elections they got an empty box opponent. The focus of attention in the elections is no longer taking into account the movements and strategies of political opponents, but it shifts to how to increase public participation to come to polling stations during this pandemic. The election took place at a time when the spike in COVID-19 cases continued to increase and Indonesia had not been able to overcome the first wave of the COVID-19 pandemic. This is a scourge for the successful team. If the number of people who come is less, then it does not rule out the possibility that the Hendi-Ita pair will lose from an empty box because they do not meet the minimum vote acquisition threshold against an empty box. Fighting an empty box does not mean that they are not targeting the number of votes, but rather having to work more so that the percentage of votes is above the stipulated number of votes. It turned out that the results of the vote exceeded the target of the vote, which was $92 \%$ from $85 \%$.

The applied forms and types of campaigns are through offline and online methods. The success team is still adopting some of the political strategies carried out in the 2015 regional head election which are still relevant to be used for campaigning in this new normal era such as still visiting areas in Semarang City through limited meetings attended by only a few people by applying standard health protocols. The number of 
people campaigning by conducting direct inspections to the public is limited to only around 20 people. There is no new way in the 2020 election campaign, but this time the campaign is more focused on online campaigns by utilizing social media such as Facebook, Instagram, Twitter, and online news media.

The implementation of democracy in the era of the Covid-19 Pandemic is closely related to the use of information and communication technology in involving citizens to support the democratic decision-making process and strengthen representative democracy. The implementation of democracy can also be referred to as e-democracy which aims to attract wider and more active citizen participation through the Internet (online). Rutger University research suggests that political messages on websites contribute to a more participatory implementation of direct democracy [10]. It has potential because: 1 . The inherent nature of interactivity on the internet, 2. Potential for lateral and horizontal communication, 3. Point to point communication, 4. Low cost, 5. As a fast communication medium, 6. Lost or reduced national boundaries, 7. Free from Interference.

The Hendi-Ita pair maximized the use of online campaigns and this was in accordance with KPU regulations, namely PKPU Number 13 of 2020 concerning Continuing Simultaneous Regional Elections in Non-natural Disaster Conditions COVID19. Furthermore, the KPU has regulated the campaign method for election participants, namely the face-to-face meeting and dialogue campaign through social media and online media. The regulation is stated in Article 58 of PKPU Number 13 of 2020. In its regulations The KPU expressly prohibits campaigns that are mass gathering, but it still allows campaign socialization through online media or social media [11].

The vote gained from Hendi-Ita pair reached $92 \%$ which was quite high. Based on the results of the study, there was no specific strategy or political approach. This is due to several factors that are considered very profitable for the Hendi-Ita pair. One of them is the absence of political polarization in Semarang city. This can be seen when political parties outside the party carrying the candidate Hendi-Ita also support the pair even though their position is outside as the supporting party. The pair of Hendi-Ita as the sole candidate raises the assumption that this pair has received approval from all parties. In the end, people supporting a political party who are outside the party nominating the candidate make a choice to choose the Hendi-Ita pair. This is also due to the appropriate online political campaign strategy carried out by the success team even though there are differences in campaign procedures which are considered more stringent because there are rules from the KPU regarding campaign procedures during the pandemic.

\section{Digital Campaign}

Hendi-Ita's special way of maintaining relations with the community is by opening wide communication through social media and others. Opening a communication room is one of the programs that excels such as Hendi reports. The public can submit complaints, criticisms, and suggestions through the Hendi report. The purpose of this program is to build Semarang City into a smart city. This program has been successfully implemented in Semarang City and has received a positive response from the community. According to the success team, this is one of Hendi-Ita's achievements and a flagship program because not all regional heads open information spaces open to the public.

Other promotional media is by utilizing existing social media. Some examples of Instagram as a platform for campaigns are through the accounts @smg-hit, @hendi_ita, and @ rehita_hebat. The Hendi-Ita candidate pair also campaigned through their respective social media accounts, such as Hendrar Prihadi's Instagram account, @hendrarprihadi and Hevearita Gunaryanti Rahayu's Instagram account, @mbakitasmg. Even though they are in the midst of a pandemic where space is limited, the single pairs in the 2020 Pilkada have not lost their strategy to greet the public directly. One of which is by implementing a virtual campaign box.

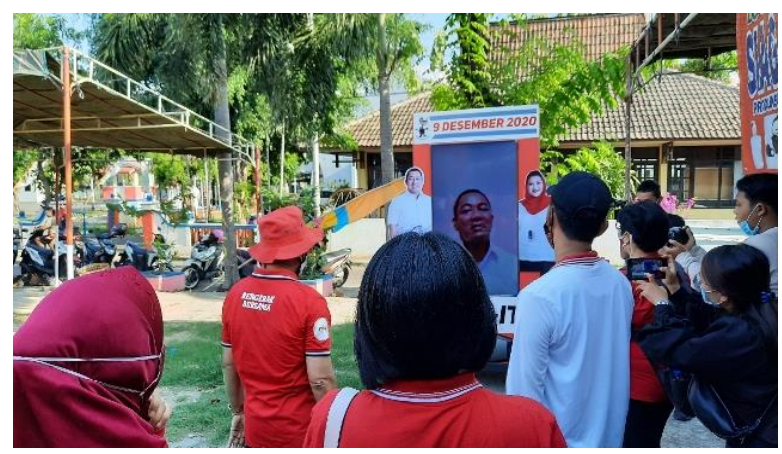

Figure 2. Virtual Box Campaign for Semarang City Election incumbent 2020

(source: https://halosemarang.id/siasati-aturankampanye-di-masa-pandemi-calon-wali-kota-semarangkampanye-dengan-virtual-box)

In the virtual campaign, Hendi-Ita did not forget to remind the residents of Semarang City to apply the $4 \mathrm{M}$, namely to wear masks, wash hands, maintain distance, and read prayers. The virtual campaign by presenting directly the Hendi-Ita pair certainly attracted the attention of the public. Another creative campaign is placing hand washing robots in several places in Semarang City. This hand washing robot works by calling everyone who passes by to remind them to wash their hands. This method is carried out as a campaign innovation that is adapted to the situation and 
conditions. Interactive digital campaigns, virtual boxes, holograms, video mapping, and hand washing robots made the campaign more attractive to the public's attention and sympathy. Towards the D day of the election, Hendi-Ita conducted a virtual grand campaign with more than 26,000 thousand participants from Semarang City on December 4, 2020 using the zoom application. This is a promotional strategy at the end of the campaign period.

\section{CONCLUSION}

The study concludes that there are several Communication Strategies used by Incumbents Hendi and Ita in the 2020 Pilkada. First, the pair still used successful team known as the Great Volunteer Team which also had influencers. This is what makes the team optimistic that the movement through social media would be very effective. In the organizational structure of the 2020 campaign, there were no shifts or additions and reductions in the number of members. This was done to make it easier to develop new winning strategies during the COVID-19 pandemic and also to minimize internal conflicts. Second, there was Hendi-Ita support community in every area. This strategy is used to facilitate the dissemination of information to the smallest scope of the community which is villages. Third is the use of New Media in the midst of the Covid-19 pandemic. Interaction activities directly or offline activities are now limited and they switch to online meetings. The success team still adopted some of the political strategies carried out in the 2015 local elections which were still relevant to be used for campaigning in the new normal era. The number of people campaigning by conducting direct inspections to the public was limited to only around 20 people. There was no new way in the 2020 election campaign, but this time the campaign was more focused on online campaigns by utilizing social media such as Facebook, Instagram, Twitter, and online news media. Fourth is Digital Campaign by utilizing existing social media through @smg-hit, @hendi_ita, and @ rehita_hebat accounts. The Hendi-Ita candidate pair also campaigned through their respective social media accounts, such as Hendrar Prihadi's Instagram account, @hendrarprihadi and Hevearita Gunaryanti Rahayu's Instagram account, @mbakitasmg. They also used a relatively new campaign strategy, namely through the campaign box.

\section{REFERENCES}

[1] "Jaringan Dokumentsi dan Informasi Hukum Komisi Pemlihan Umum," [Online]. Available: https://jdih.kpu.go.id/peraturan-kpu.

[2] A. Makkuraga, "Penggunaan New Media sebagai Sarana Kampanye Politik pada Kontestasi Pilkada Jabar 2018," Jurnal Visi Komunikasi, vol. 16, no. 2, pp. 55-68, 2017.

[3] J. Habermas, Ruang Publik, Sebuah Kajian tentang Kategori Masyarakaat Borjuis, 3rd ed., Yogyakarta: Kreasi Wacana, 2010.

[4] A. Pradhanawati, N. Farida, W. Abdulrahman, and M. Hanura, "Perilaku Pemilih Menjelang Pilkada Serentak 2015 di Kota Semarang," Jurnal Ilmu Sosial, vol. 15, no. 1, pp. 63-69, 2016.

[5] J. W. Creswell, Research Design Pendekatan Kualitatif, Kuantitatif dan Mixed, Yogyakarta: Pustaka Pelajar, 2013.

[6] B. Bungin, Penelitian Kualitatif, Jakarta: Kencana Prenada Media, 2014.

[7] Sugiyono, Memahami Penelitian Kualitatif, Bandung: Alfabeta, 2017.

[8] Emzir, Metode Penelitian Kualitatif Analisis Data, Jakarta: Raja Grafindo Persada, 2010.

[9] J. Indrawan, Efriza, and A. Ilman, "Kehadiran Media Baru (New Media) dalam Proses Komunikasi Politik," Jurnal Medium Universitas Islam Riau, vol. 8, no. 1, p. 167, 2018.

[10] L. L. Kaid, Handbook of Political Communication Research, London: Lawrence Erlbaum Associates Publishers, 2004.

[11] S. C. Dewanti, "Kebijakan Kampanye secara Daring pada Pilkada Serentak 2020," Info Singkat: Bagian Politik dalam Negeri Kajian Singkat terhadap Isu Aktual dan Strategis, vol. XII, no. 19, pp. 25-30, 2020. 